\title{
SISTEM INFORMASI PELAYANAN SURAT KETERANGAN PADA KANTOR DESA HONGGOSOCO (SI SUKET)
}

\author{
Muhammad Sholikhul Huda ${ }^{1}$, Nanik Susanti ${ }^{2}$ \\ 1,2 Sistem Informasi Fakultas Teknik Universitas Muria Kudus \\ Email:2nanik.susanti@umk.ac.id
}

(Naskah masuk: 15 Juni 2021, diterima untuk diterbitkan: 25 Juni 2021)

\begin{abstract}
Abstrak
Surat menyurat merupakan salah satu jenis pelayanan yang terpenting yang ada di setiap kantor desa. Demikin halnya yang terjadi pada kantor Desa Honggosoco Kecamatan Jekulo Kabupaten Kudus. Terdapat sejumlah jenis surat yang biasanya dilayani oleh desa seperti surat pernyataan, surat keterangan kelahiran, surat keterangan kematian, surat keterangan tidak mampu, surat keterangan serbaguna, surat keterangan domisili , surat keterangan berkelakuan baik, surat keterangan usaha dan beberapa surat-surat lainnya. dalam pelaksanaannya terdapat kendala yaitu para Kaur Umum harus mengetik isi surat secara manual. Hal ini bisa menghambat kinerja pelayanan surat keterangan di balai Desa dan menyebabkan penumpukan antrian warga yang akan membuat surat keterangan. Selain itu, pengarsipan yang masih manual menggunakan buku menjadi masalah tersendiri. Pengarsipan secara manual dengan buku beresiko terjadi kehilangan data, misalnya apabila terjadi kebakaran, buku terselip, hilang dan sebagainya. Dari permasalahan tersebut perlu dikembangkan sistem informasi berbasis web yang dapat memberikan solusi untuk mengatasi permasalahan tersebut, utamanya pada kegiatan pelayanan surat menyurat pada kantor desa. Metode pengembangan yang diterapkan pada penelitian ini adalah dengan pengembangan metode SDLC (System Development Life Cycle). Dengan tahapan investigate, analyze, desain, implementasi dan perawatan system. Pada penelitian ini menghasilkan aplikasi SI SUKET yang mampu membantu pihak kantor desa dalam menyediakan pelayanan pembuatan surat keterangan secara mandiri dan berbasis web (online).
\end{abstract}

Kata kunci: SI SUKET, Surat Keterangan, Desa, Online

\section{INFORMATION SYSTEM FOR CERTIFICATE SERVICES AT THE HONGGOSOCO VILLAGE OFFICE (SI SUKET)}

\begin{abstract}
Correspondence is one of the most important types of services available in every village office. Such is the case at the Honggosoco Village office, Jekulo District, Kudus Regency. There are a number of types of letters that are usually served by the village such as statement letters, birth certificates, death certificates, disability certificates, multipurpose certificates, domicile certificates, certificates of good behavior, business certificates and several other documents. in its implementation there are obstacles, namely the General Kaur must type the contents of the letter manually. This can hamper the performance of the certificate service at the Village hall and cause a buildup of queues of residents who will make a certificate. In addition, manual archiving using books is a problem in itself. Archiving manually with books is at risk of data loss, for example in the event of a fire, books are tucked away, lost and so on. From these problems, it is necessary to develop a web-based information system that can provide solutions to overcome these problems, especially in correspondence service activities at the village office. The development method applied in this research is the development of the SDLC (System Development Life Cycle) method. With the stages of investigation, analyze, design, implementation and maintenance of the system. In this study resulted in the SI SUKET application which is able to assist the village office in providing services for making certificates independently and web-based (online).
\end{abstract}

Keywords: SI SUKET, Certificate, Village, Online 


\section{PENDAHULUAN}

Menurut UU No. 6 Tahun 2014 Pemerintah Desa merupakan penyelenggaraan urusan pemerintahan serta kepentingan warga setempat dalam sistem pemerintah Negara Kesatuan Republik Indonesia yang bertugas memenuhi kebutuhan dasar warganya. (Zainudin, 2016)

Desa merupakan pelaksana tata pemerintahan terkecil Negara ysng mempunyai tanggung jawab memberikan perlindungan dan pengakuan terhadap penentuan status pribadi dan status hukum warganya. Antara lain perubahan nama, alamat, pernikahan, kelahiran, kematian, perceraian, pindah datang untuk menetap, serta perubahan status orang asing tinggal terbatas menjadi tinggal tetap, perubahan status hak asuh anak serta perubahan status kewarganegaraan. Hal ini merupakan kejadian penting yang dialami oleh setiap warga yang harus dilaporkan ke pihak desa untuk dilakukan pendataan karena membawa dampak perubahan data identitas atau surat keterangan kependudukan. (Faqih, 2018)

Desa Honggosoco adalah salah satu desa di Kecamatan Jekulo Kabupaten Kudus. Desa Honggosoco terletak di kecamatan Jekulo paling barat laut yang berbatasan langsung dengan kecamatan Dawe di sebelah utaranya dan kecamatan Bae sebelah baratnya. Struktur pemerintahan di Desa Honggosoco terdiri dari Kepala Desa, Badan Permusyawaratan Desa, Sekretaris Desa, Kepala Urusan Pemerintah, Kepala Urusan Pembangunan, Kepala Urusan Kesejahteraan Rakyat, Kepala Urusan Keuangan, Kepala Urusan Umum, Kepala Dusun, dan Administrasi Desa. Desa Honggosoco memiliki luas 502,852 ha dan yang digunakan sebagai pemukiman seluas 195,530 ha. Desa Honggosoco Kecamatan Jekulo Kabupaten Kudus dibagi menjadi 3 Dusun, 5 RW, dan 31 RT dengan jumlah total penduduk 10943 Jiwa. Dari hasil pengamatan, setiap hari pasti ada penduduk Desa memerlukan surat yang dikeluarkan dari desa. Maka dari itu, surat menyurat merupakan salah satu jenis pelayanan yang terpenting yang ada di setiap kantor desa. Keperluan surat menyurat Penduduk di sebuah Desa dibuat oleh Kepala Urusan Umum. Terdapat sejumlah jenis surat yang biasanya dilayani oleh desa seperti surat pernyataan, surat keterangan kelahiran, surat keterangan kematian, surat keterangan tidak mampu, surat keterangan serbaguna, surat keterangan domisili, surat keterangan berkelakuan baik, surat keterangan usaha dan beberapa surat-surat lainnya.

Pencatatan dan pengolahan data penduduk merupakan tugas dari dinas kependudukan dan pencatatan sipil di tingkat kabupaten, namun pelaksanaannya diawali dari pihak desa selaku ujung tombak pendaftaran dan pengelolaan data penduduk. Pihak desa wajib memberikan pelayanan yang cepat dan tepat untuk mendapatkan informasi yang dibutuhkan warganya. Akan tetapi, dalam pelaksanaannya terdapat kendala yaitu para Kaur Umum harus mengetik isi surat secara manual. Hal ini bisa menghambat kinerja pelayanan surat keterangan di balai Desa dan menyebabkan penumpukan antrian warga yang akan membuat surat keterangan. Selain itu, pengarsipan yang masih manual menggunakan buku menjadi masalah tersendiri. Pengarsipan secara manual dengan buku beresiko terjadi kehilangan data, misalnya apabila terjadi kebakaran, buku terselip, hilang dan sebagainya.

\section{METODOLOGI PENELITIAN}

Metode pengembangan yang diterapkan pada penelitian ini adalah dengan pengembangan metode SDLC (System Development Life Cycle). SDLC merupakan gambaran dari upaya merancang sistem yang bergerak seperti roda melalui beberapa fase termasuk fase penyelidikan(investigate)analisis desain implementasi, dan pemeliharaan. Tahapan selanjutnya akan kembali pada tahap penyelidikan(investigate) jika di rasakan bahwa sistem yang ada sudah tidak efisien lagi untuk diterapkan. Maka ada pepatah mengatakan bahwa suatu sistem tidak pernah dianggap selesai dan selalu terbuka peluang untuk mengembangkan sesuai dengan perkembangan jaman. Tahapan pada model SDLC meliputi:

1. Tahap Perencanaan / Investigation.

Tahap Perencanaan berkenaan dengan studi awal untuk membangun sistem baru dengan mendefinisikan masalah yang muncul dalam sistem secara umum. Tahap perencanaan dilakukan wawancara dan observasi

a. Wawancara

Pada tahap ini penulis melakukan wawancara kepada kepada Kaur Umum mengenai alur administrasi surat keterangan. Didalam pelaksanaannya terdapat kendala yaitu prose pembuatan surat secara manual yang menyebabkan penumpukan antrian surat permohonan oleh warga serta pengarsipan yang masih manual. Hal ini bisa menghambat kinerja pelayanan surat keterangan di balai Desa serta pengarsipan secara manual dengan buku beresiko terjadi kehilangan data

b. Observasi

Pada tahap ini penulis melakukan magang di Balai Desa dengan membantu Kaur Umum dalam melayani pembuatan surat keterangan bagi warga yang akan membuat surat keterangan sesuai dengan keperluan masing-masing sehingga penulis dapat mengumpulkan informasi mengenai data apa saja yang dibutuhkan dalam pembuatan aplikasinya..

2. Tahap Analisis.

Analisis sistem dapat diartikan sebagai suatu proses untuk memahami sistem yang ada dengan tujuan untuk merancang sistem baru atau diperbaharui. Pada 
tahap ini penulis mengumpulkan data yang diperlukan dalam pembuatan sistem. Kebutuhan data meliputi Data User sebagai pengguna system, Data warga (pemohon surat), Data surat keterangan, Data arsip surat. Sedangkan untuk kebutuhan informasi meliputi: Laporan surat keterangan dan Laporan data arsip surat

3. Tahap Perancangan / Desain sistem.

Pada tahap selanjutnya adalah pembuatan rancangan atau desain sistem baru yang dapat digunakan serta bisa beroperasi dengan lebih baik, harapanya bisa memberikan solusi dari permasalahan yang ada serta sebisa mungkin bisa mencegah kemungkinan hal-hal yang terjadi di masa yang akan datang. Kegunaan rancanga atau desain sistem baru ini memberikan gambaran rancang bangun (blueprint) yang lengkap, untuk pedoman bagi pembuat program atau programmer dalam membuat dan mengembangkan aplikasi.

Pada tahap ini penulis melakukan perancangan system baru dengan berpedoman pada Analisa kebutuhan data dan informasi yang didapat pada tahap wawancara dan observasi yang dilakukan. Kegiatan yang dilakukan meliputi:

1) Perancangan use case diagram

2) Perancangan basisdata dan tabel serta

3)Perancangan User interface.

\section{Tahap Penerapan}

Pada tahap ini penulis membuat program sebagai tahapan kegiatan dari perancangan yang telah sesuai dengan kebutuhan pengguna dan pihak - pihak yang terkait dalam implementasi system nanti ke dalam aplikasi melalui bahasa pemrograman.

Selain pembuatan program juga dilakukan Pengujian aplikasi dengan melibatkan user secara langsung, baik dari pihak Kaur Umum, pemohon/warga serta kepala desa. Proses pengujian menggunakan metode whitebox dan blackbox testing untuk menguji keakuratan data serta proses jalanya aplikasi.

\section{Tahap pemeliharaan}

Dalam penggunaan sistem dipandang perlu adanya pemeliharaan system yang bertujuan untuk memastikan bahwa aplikasi SI SUKET berjalan sesuai harapan user. Apabila terdapat kesalahan yang disebabkan oleh system error maka bisa segera diperbaiki untuk menjaga update sistem, dan meningkatkan kinerja sistem

\section{HASIL DAN PEMBAHASAN}

Pada pelayanan surat keterangan yang sedang berjalan di Pemerintah Desa Honggosoco menggunakan teknologi informasi dengan memanfaatkan program microsoft word. Surat keterangan dibuat dan dikeluarkan oleh pihak pemerintah desa melalui Kaur Umum. Kaur Umum membuat sebuah template yang berisikan nomor surat, data diri pemohon, keperluan, masa berlaku, keterangan lainnya, tanda tangan kepala desa atau sekdes. Dalam proses pembuatannya,
Pemohon datang ke balai desa dengan membawa data diri (KTP atau KK) kemudian mengantri untuk dilayani dalam pembuatan surat keterangan oleh Kaur Umum. Pemohon menyerahkan data diri (KTP atau KK) kepada Kaur Umum untuk dimasukkan data dirinya kedalam surat keterangan. Kaur Umum mengetik data diri pemohon dan keperluan pemohon meminta surat keterangan secara manual dengan menggunakan template yang sudah dibuat. Pada proses pengetikan ini yang biasanya berjalan lambat, karena seluruh data diri diketik secara manual, seperti nomor surat, nama, TTL, kewarganegaraan, agama, pekerjaan, alamat tempat tinggal, keperluan, tanggal berlaku, dan penanggung jawab surat. Proses pembuatan surat yang seperti itu dapat menghambat kinerja dari Kaur Umum dan Stafnya. Hal ini tentu tidak sejalan dengan visi dan misi pemerintah Desa .

Selain itu, proses pengarsipan surat masih dilakukan secara manual ditulis didalam buku folio. Pengarsipan dokumen dengan buku manual dirasa sangat mengkhawatirkan karena sewaktuwaktu arsip tersebut bisa saja rusak, hilang, terselip, dsb. Maka dari itu, sistem yang dibuat diharapkan bisa digunakan untuk mengarsipkan surat keterangan sehingga arsip surat keterangan yang ada di Pemerintah Desa berupa soft file. Apabila file arsip surat keterangan berupa soft file, suatu surat akan lebih mudah dicari dan akan lebih mudah dalam melakukan backup data agar tidak hilang.

Pada penelitian ini menghasilkan aplikasi system informasi pelayanan surat keterangan yang disingkat dengan SI SUKET. Gambar 1 merupakan diagram sistem use case SI SUKET Sistem Pelayanan Surat Keterangan di Kantor Desa Honggosoco Berbasis WEB. yang akan menjelaskan jalannya system secara umum yang mudah dibaca, pengguna sistem (aktor) dan aktifitas dari pengguna system tersebut (use case).

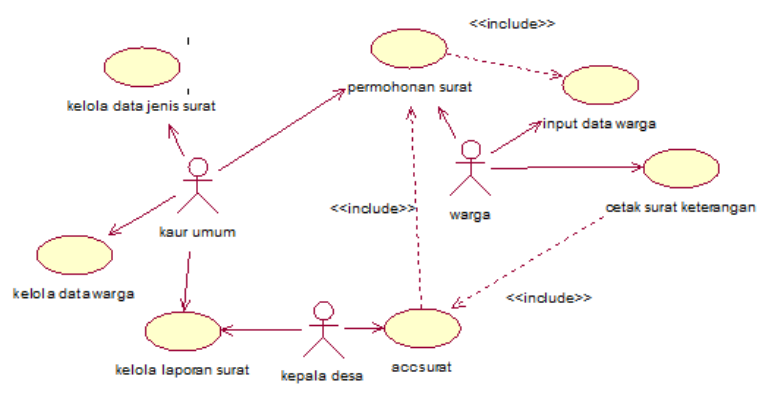

Gambar 1 Sistem Use Case

Table 1 Proses Bisnis

\begin{tabular}{|l|l|l|l|}
\hline No & Proses Bisnis & Aktor & $\begin{array}{l}\text { Sistem Use } \\
\text { Case }\end{array}$ \\
\hline
\end{tabular}




\begin{tabular}{|c|c|c|c|}
\hline 1. & $\begin{array}{lr}\text { Pada } & \text { proses } \\
\text { pembuatan } & \text { surat, } \\
\text { warga menginput } & \text { mata diri rendiri } \\
\text { data } & \text { sesuai dengan } \\
\text { dan KK } & \end{array}$ & warga & $\begin{array}{l}\text { Input data } \\
\text { warga }\end{array}$ \\
\hline 2 & $\begin{array}{l}\text { Warga mengajukan } \\
\text { permohonan dengan } \\
\text { memilih jenis surat } \\
\text { keterangan sesuai } \\
\text { dengan keperluan dan } \\
\text { kemudian kaur } \\
\text { mengecek } \\
\text { kelengkapan surat }\end{array}$ & $\begin{array}{l}\text { Warga } \\
\text { dan } \\
\text { Kaur } \\
\text { umum }\end{array}$ & $\begin{array}{l}\text { Permohonan } \\
\text { Surat }\end{array}$ \\
\hline 3 & $\begin{array}{l}\text { Kaur umum dapat } \\
\text { tambah,simpan, } \\
\text { ubah, hapus data jenis } \\
\text { surat. Jadi, apabila } \\
\text { ingin menambah } \\
\text { jenis surat atau } \\
\text { mengubah jenis surat, } \\
\text { kaur umum tidak } \\
\text { perlu mengubahnya } \\
\text { lewat coding. Cukup } \\
\text { mengubahnya lewat } \\
\text { sistem. }\end{array}$ & $\begin{array}{l}\text { Kaur } \\
\text { umum }\end{array}$ & $\begin{array}{l}\text { Kelola data } \\
\text { jenis surat }\end{array}$ \\
\hline 4. & $\begin{array}{l}\text { Kaur umum dapat } \\
\text { tambah,simpan, } \\
\text { ubah, hapus data } \\
\text { warga. Hal ini dapat } \\
\text { berfungsi apabila ada } \\
\text { perubahan data } \\
\text { warga. }\end{array}$ & $\begin{array}{l}\text { Kaur } \\
\text { umum }\end{array}$ & $\begin{array}{l}\text { Kelola data } \\
\text { warga }\end{array}$ \\
\hline 5 . & $\begin{array}{lr}\begin{array}{l}\text { Data surat yang telah } \\
\text { dibuat }\end{array} & \text { akan } \\
\text { tersimpan pada tabel } \\
\text { laporan } \\
\text { nantinya bisa di cek } \\
\text { dan dicetak sesuai } \\
\text { dengan kebutuhan. } \\
\text { Misalnya kaur umum } \\
\text { akan membuat } \\
\text { laporan pembuatan } \\
\text { surat keterangan } \\
\text { selama 1 bulan. } \\
\text { kepala desa juga bisa } \\
\text { cek laporan dan cetak } \\
\text { laporan. }\end{array}$ & $\begin{array}{l}\text { Kaur } \\
\text { umum } \\
\text { dan } \\
\text { kepala } \\
\text { desa }\end{array}$ & $\begin{array}{l}\text { Kelola } \\
\text { Laporan } \\
\text { surat }\end{array}$ \\
\hline 6. & $\begin{array}{l}\text { Surat yang diajukan } \\
\text { oleh warga harus } \\
\text { mendapat persetujuan } \\
\text { dari kepala desa }\end{array}$ & $\begin{array}{l}\text { Kepala } \\
\text { desa }\end{array}$ & Acc surat \\
\hline 7 & $\begin{array}{l}\text { Surat keterangan } \\
\text { yang sudah bertanda } \\
\text { tangan dan stempel } \\
\text { bisa di download dari } \\
\text { sistem oleh warga } \\
\text { untuk dicetak }\end{array}$ & warga & $\begin{array}{l}\text { Cetak surat } \\
\text { keterangan }\end{array}$ \\
\hline
\end{tabular}

Relasi antar tabel pada database yang terbentuk untuk pembuatan Sistem Informasi Pelayanan Surat Keterangan di Kantor Desa Berbasis WEB ditunjukan pada gambar 2 berikut ini.

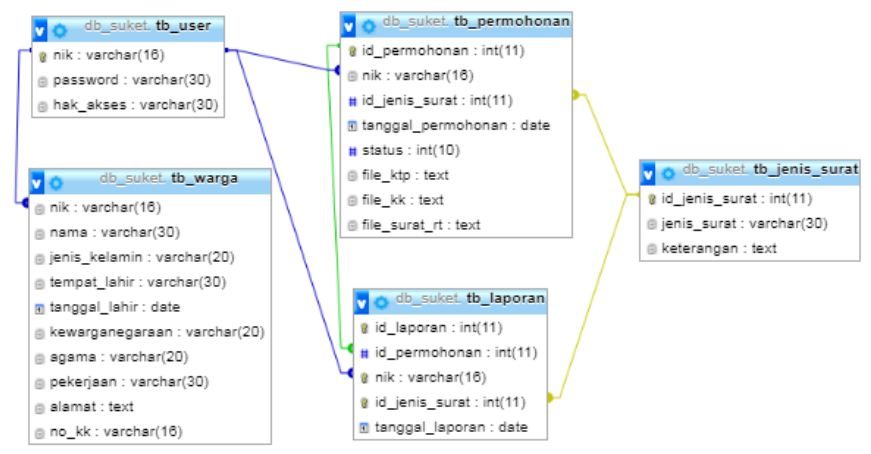

Gambar 2 Relasi Tabel

Tampilan halaman Login Warga pada Sistem Informasi Pelayanan Surat Keterangan di Kantor Desa Berbasis WEB dapat dilihat pada gambar berikut ini.

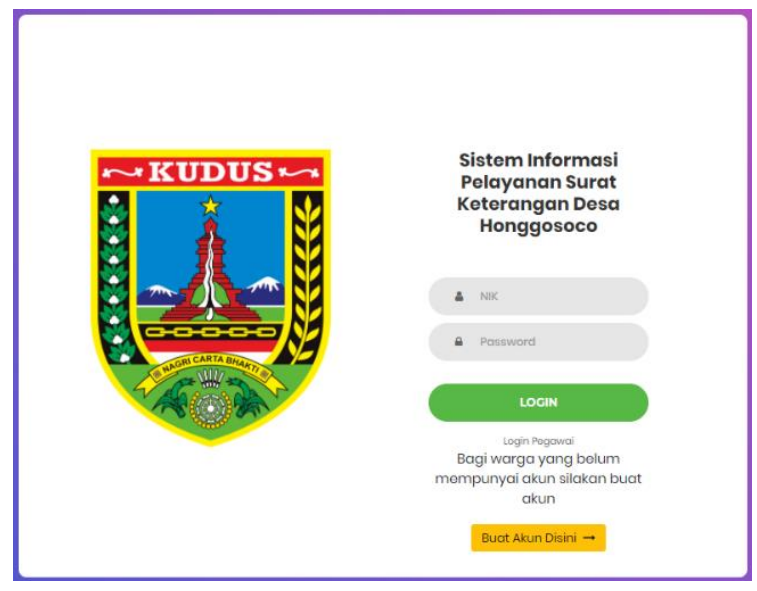

Gambar 3 Login Sistem

Tampilan pembuatan surat baru pada Sistem Informasi Pelayanan Surat Keterangan di Kantor Desa Berbasis WEB dapat dilihat pada gambar 4 berikut ini.

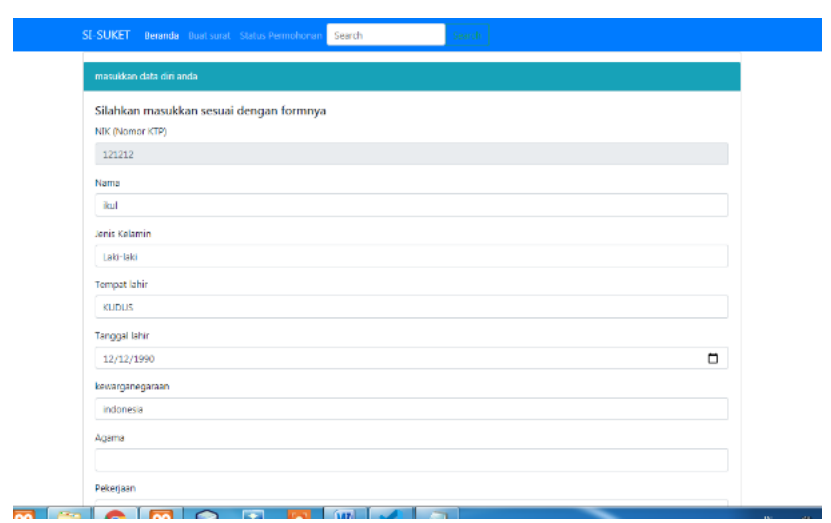


Tampilan memilih jenis surat yang akan dibuat pada Sistem Informasi Pelayanan Surat keterangan di Kantor Desa Honggosoco Berbasis WEB dapat dilihat pada gambar berikut ini.

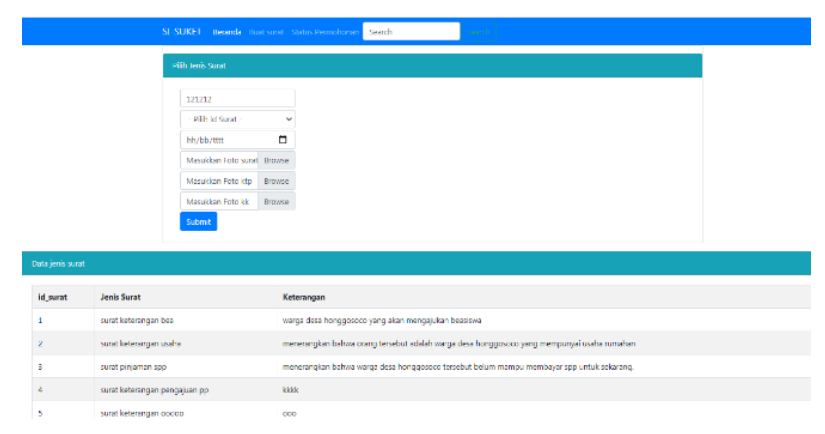

\section{Gambar 5 Tampilan Pilih Surat}

Tampilan Status Permohonan surat pada Sistem Informasi Pelayanan Surat Keterangan di Kantor Desa Honggosoco Berbasis WEB dapat dilihat pada gambar berikut ini.

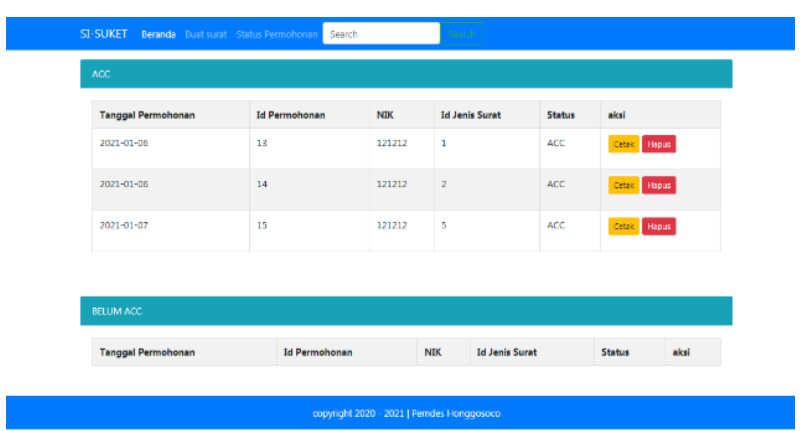

Gambar 6 Tampilan Status Permohonan

Tampilan surat keterangan untuk pemohon yang sudah mendapatkan persetujuan daan legalitas dari kantor desa yang bisa di cetak sendiri oleh pemohon pada Sistem Informasi Pelayanan Surat Keterangan di Kantor Desa Honggosoco Berbasis WEB dapat dilihat pada gambar 7 berikut ini.

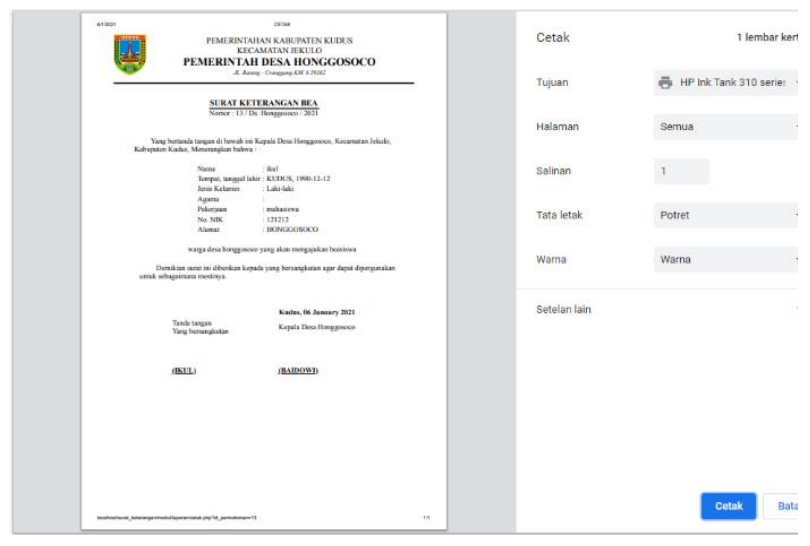

Gambar 7 Tampilan Cetak Surat

\section{KESIMPULAN DAN SARAN}

Kesimpulan yang diperoleh berdasar pada kegiatan investigasi, analisa perancangan, penerapan serta pembahasan maka bisa diambil beberapa point kesimpulan sebagai berikut :

1. Aplikasi SI SUKET ini merupakan aplikasi Pelayanan Surat Keterangan di Kantor Desa Berbasis WEB ini dibuat dengan menggunakan bahasa pemrograman PHP dan MySQL sebagai basis datanya

2. Sistem ini dibuat untuk menyediakan pelayanan pembuatan surat keterangan secara mandiri dan berbasis web (online).

3. Informasi atau luaran yang diperoleh dari proses data adalah berupa surat keterangan yang dikeluarkan dari Pemerintah Desa serta laporan pembuatan surat keterangan periodik dan berkala perbulan dan pertahun.

Adapun saran dari penulis yang diharapkan mampu melengkapi kekurangan dari sistem yang telah dibangun yaitu:

1. Aplikasi bisa dikembangkan lebih lanjut secara userfriendly pada aplikasi mobile.

2. Sistem bisa diintegrasikan langsung dengan data penduduk Desa Honggosoco Sehingga dapat mengurangi resiko kesalahan dan mencegah penduduk desa lain untuk memasuki sistem ini.

3. Sistem dapat dikembangkan menjadi portal informasi desa bagi Warga Desa Honggosoco.

\section{DAFTAR PUSTAKA}

Abdullah, Dahlan. 2017. Merancang Aplikasi Perpustakaan Menggunakan SDLC. Lhokseumawe : Sefa Bumi Persada.

Alfianti, Henny dan Aris Haris Rismayana. 2020. Sistem Administrasi Pelayanan Surat Mahasiswa Berbasis Web Dan Mobile Android. Jurnal Infotekmesin, Vol.11, No.02 : 94-101.

Faqih, Misbahun. 2018 Sistem Informasi Pelayanan Surat-Menyurat Berbasis Web Di Desa Palang Kecamatan Palang Kabupaten Tuban

Priyadi, Didin Agus dan Lestari Endah Wiji, 2018 Perancangan Sistem Informasi Pelayanan Surat Menyurat Pada Kantor Desa Tanjungsari Kutowinangun Kebumen Berbasis Desktop. Jurnal Teknik Komputer AMIK BSI Vol IV No.2 Bulan Agustus

Sukrianto, Darmanta. 2017. Penerapan Teknologi Barde Pada Pengolahan Data Pembayaran Sumbangan Pembinaan 
80 Indonesian Journal of Technology, Informatics and Science (IJTIS), Vol. 2, No. 2, Juni 2021, hlm. 75-80

Pendidikan (SPP). Jurnal Intra-Tech, Vol. 1, No.2 : 18-27.

Unhelkar, Bhuvan. 2018. Software Engineering with UML. Boca Raton : CRC Press.

Winarna, Tio Renndy, Ismiarta Aknuranda dan Mochamad Chandra Saputra. 2018. Pengembangan Sistem Informasi Pelayanan Surat Keterangan Studi Kasus: Pemerintah Desa Legundi Kecamatan Karangjati Kabupaten Ngawi. Jurnal Pengembangan Teknologi Informasi dan Ilmu Komputer, Vol. 2, No. 12 : 6235-6243.

Zainudin, Arif. 2016. Model Kelembagaan Pemerintahan Desa. Jurnal Ilmu Pemerintahan : Kajian Ilmu Pemerintahan dan Politik Daerah, Vol.1 , No.2 : 338-351 